\title{
Fe(III) mineral formation and cell encrustation by the nitrate-dependent Fe(II)-oxidizer strain BoFeN1
}

\author{
A. KAPPLER, ${ }^{1, *}$ B. SCHINK ${ }^{2}$ AND D. K. NEWMAN ${ }^{1}$ \\ ${ }^{1}$ GPS Division, California Institute of Technology, Pasadena, CA 91125, USA \\ ${ }^{2}$ Fachbereich Biologie, Universität Konstanz, D-78457 Konstanz, Germany \\ *Present address: Geomicrobiology Group, Center for Applied Geosciences, University of Tübingen, D-72074 Tübingen, Germany
}

\begin{abstract}
Understanding the mechanisms of anaerobic microbial iron cycling is necessary for a full appreciation of presentday biogeochemical cycling of iron and carbon and for drawing conclusions about these cycles on the ancient Earth. Towards that end, we isolated and characterized an anaerobic nitrate-dependent Fe(II)-oxidizing bacterium from a freshwater sediment. The 16SrRNA gene sequence of the isolated bacterium (strain BoFeN1) places it within the $\beta$-Proteobacteria, with Acidovorax sp. strain G8B1 as the closest known relative. During mixotrophic growth with acetate plus Fe(II) and nitrate as electron acceptor, strain BoFeN1 forms Fe(III) mineral crusts around the cells. The amount of the organic cosubstrate acetate present seems to control the rate and extent of Fe(II) oxidation and the viability of the cells. The crystallinity of the mineral products is influenced by nucleation by Fe minerals that are already present in the inoculum.
\end{abstract}

Received 25 July 2005; accepted 14 December 2005

Corresponding author: A. Kappler, Tel.: +49-7071-2974992; fax: +49-7071-295139; e-mail: andreas.kappler@uni-tuebingen.de.

\section{INTRODUCTION}

Microbial reduction of ferric iron [Fe(III)] plays a major role in mineralization of organic carbon in freshwater and marine environments as well as in soils (Lovley, 1991; Thamdrup, 2000). The product of this metabolism, i.e. ferrous iron $[\mathrm{Fe}(\mathrm{II})]$, is reoxidized to $\mathrm{Fe}(\mathrm{III})$ at neutral or alkaline $\mathrm{pH}$ by molecular oxygen $\left(\mathrm{O}_{2}\right)$ in a chemical reaction, whereas under acidic conditions, $\mathrm{Fe}(\mathrm{II})$ remains stable (Stumm \& Morgan, 1996). Micro-organisms can catalyse the aerobic oxidation of $\mathrm{Fe}(\mathrm{II})$ at acidic (Wood, 1988; Blake et al., 1993; Blake \& Johnson, 2000) and neutral pH (Hanert, 1981; Wood, 1988; Emerson \& Revsbech, 1994; Emerson, 2000) and successfully compete with chemical oxidation. The discovery of phototrophic (Widdel et al., 1993) and nitrate-dependent $\mathrm{Fe}(\mathrm{II})$ oxidizers (Straub et al., 1996; Benz et al., 1998) showed that micro-organisms can close the iron cycle not only under oxic but also under anoxic conditions, thus increasing the importance of $\mathrm{Fe}(\mathrm{III})$ as electron acceptor for carbon mineralization under anoxic conditions.

$\mathrm{Fe}$ (II) oxidation under $\mathrm{O}_{2}$-free conditions not only plays a role in modern biogeochemical cycling of iron and carbon. Also for a long period in early Earth history virtually no $\mathrm{O}_{2}$ was available for chemical or microbial oxidation of $\mathrm{Fe}(\mathrm{II})$. Therefore, it is likely that anaerobic, $\mathrm{O}_{2}$-independent oxidation of $\mathrm{Fe}$ (II) also contributed to Fe cycling in the past, as evidenced by the deposition of Precambrian iron mineral deposits (Banded Iron Formations) during a period in Earth history preceding the presumed advent of oxygenic photosynthesis (Hartman, 1984). To date, the mechanism of anaerobic Fe(II) oxidation that has been discussed most in this context has been $\mathrm{Fe}(\mathrm{II})$ oxidation by anoxygenic phototrophs (Widdel et al., 1993; Croal et al., 2004; Kappler et al., 2005). However, anaerobic oxidation of $\mathrm{Fe}$ (II) by nitrate could also have contributed to Fe cycling in the past, although most likely at a stage in Earth history following the rise of $\mathrm{O}_{2}$, given that nitrate is a highly oxidized compound that formed in substantial amounts only after molecular oxygen was present (Beaumont \& Robert, 1999).

The biochemistry of Fe(II) oxidation has been studied in detail with aerobic acidophilic $\mathrm{Fe}$ (II) oxidizers (Blake \& Johnson, 2000); however, much less is known about the mechanisms of neutrophilic $\mathrm{Fe}(\mathrm{II})$ oxidation. The neutrophilic aerobic $\mathrm{Fe}(\mathrm{II})$ oxidizers Gallionella and Leptothrix produce extracellular organic polymers that nucleate Fe(III) precipitates. Examples include the stalks typical of Gallionella ferruginea and 
sheaths typical of Leptothrix ochracea (Emerson \& Revsbech, 1994). It has been suggested that these microbes use these strategies to avoid encrustation of the metabolizing cells that would lead to impaired substrate uptake and metabolite release, and might even cause cell death (Hanert, 1981; Hallberg \& Ferris, 2004). Nothing is known so far about the mechanism of anaerobic $\mathrm{Fe}(\mathrm{II})$ oxidation. In particular, it is not clear where in the cell or at the cell membrane Fe(II) is oxidized, how the bacteria deal with the poor solubility of the product of their metabolism, i.e. the $\mathrm{Fe}(\mathrm{III})$, and how they avoid or overcome encrustation. A microenvironment with lowered $\mathrm{pH}$ values in close cell vicinity was observed around colonies of phototrophic $\mathrm{Fe}(\mathrm{II})$ oxidizers fixed in semisolid agarose (Kappler \& Newman, 2004) in a similar manner as observed for microaerophilic Fe(II) oxidizers (Roden et al., 2004; D. Emerson, personal communication). Such acidification could help explain why these microbes do not form a $\mathrm{Fe}(\mathrm{III})$ mineral crust around their cells.

While it was demonstrated that phototrophic and microaerophilic $\mathrm{Fe}(\mathrm{II})$ oxidizers are truly lithoautotrophic microorganisms (Ehrenreich \& Widdel, 1994; Emerson \& Moyer, 1997; Sobolev \& Roden, 2004), most nitrate-dependent $\mathrm{Fe}(\mathrm{II})$ oxidizers isolated so far need an organic cosubstrate for growth (Straub et al., 1996, 2004; Benz et al., 1998; Lack et al., 2002). Only some psychrophilic, neutrophilic Feoxidizing bacteria isolated from the deep sea (Edwards et al., 2003 ) and some nitrate-dependent $\mathrm{Fe}(\mathrm{II})$-oxidizing enrichment cultures (Benz et al., 1998; Straub \& Buchholz-Cleven, 1998) oxidize $\mathrm{Fe}(\mathrm{II})$ without the addition of organic substrates. However, it has not been demonstrated that these cultures can be cultured successively for several generations with $\mathrm{Fe}(\mathrm{II})$ as the sole electron donor, and currently, no pure culture of lithotrophic nitrate-dependent $\mathrm{Fe}(\mathrm{II})$ oxidizers is available. The question still remains whether $\mathrm{Fe}(\mathrm{II})$ oxidation is beneficial for mixotrophic $\mathrm{Fe}$ (II) oxidizers at all, or whether it is just a side activity that could even be harmful for the cells because of cell encrustation.

In this study, we tried to determine how the presence of an organic cosubstrate affects the rate and extent of $\mathrm{Fe}(\mathrm{II})$ oxidation, cell encrustation and identity of the Fe(III) minerals precipitated by a newly isolated mixotrophic nitrate-dependent $\mathrm{Fe}(\mathrm{II})$-oxidizing bacterial strain.

\section{MATERIALS AND METHODS}

\section{Isolation of organism and 16S rDNA sequence analysis}

The nitrate-dependent $\mathrm{Fe}(\mathrm{II})$-oxidizing strain BoFeNl was isolated from Lake Constance littoral sediments. Sediment samples were taken at $1-2 \mathrm{~m}$ water depth at the southern shore of the north-western arm of Lake Constance (Überlinger See), close to the island Mainau where the sediment is slightly sandy and covered with limestone precipitates. Plastic core tubes $(8 \mathrm{~cm}$ diameter) were immersed into the sediment with a special handle. Inoculum material for direct dilution in agar shake tubes was taken at $1 \mathrm{~cm}$ sediment depth, at the transition zone between brownish surface sediment and grey deeper sediment. Oxygen penetrated into this sediment down to about $4 \mathrm{~mm}$ depth (Gerhardt et al., 2005). Agar shake dilutions (Widdel \& Bak, 1992) were run in bicarbonatebuffered oxygen-free nonreduced mineral medium (Ehrenreich \& Widdel, 1994), with $2 \mathrm{~mm}$ acetate, $5 \mathrm{~mm} \mathrm{FeSO}_{4}$ and $5 \mathrm{~mm}$ $\mathrm{NaNO}_{3}$ as substrates. Controls were performed with acetate plus nitrate or with ferrous sulfate plus nitrate as substrates. Colonies appearing after $4-5$ weeks of incubation at $28^{\circ} \mathrm{C}$ were diluted again in agar shake cultures and transferred into liquid medium after checking for purity by microscopic observation.

16S rDNA from $3 \mu \mathrm{L}$ cell suspension was amplified by a standard polymerase chain reaction (PCR) method using primers $8 \mathrm{~F}$ (5'-3': AGAGTTTGATCCTGGCTCAG) and 1492R (5'-3': GGTTACCTTGTTACGACTT). The PCR program was as follows: $95^{\circ} \mathrm{C}$ for $5 \mathrm{~min}$ and then 33 cycles at $95^{\circ} \mathrm{C}$ for $30 \mathrm{~s}, 50{ }^{\circ} \mathrm{C}$ for $40 \mathrm{~s}$ and $72{ }^{\circ} \mathrm{C}$ for $2 \mathrm{~min}$, followed by a 10 -min extension time at $72{ }^{\circ} \mathrm{C}$. Amplification was confirmed by agarose gel electrophoresis ( $1 \%$ agarose). For sequencing of the $16 \mathrm{~S}$ rDNA gene of strain BoFeNl, the primers $8 \mathrm{~F}, 1492 \mathrm{R}$, and the primers $50 \mathrm{~F}\left(5^{\prime}-3^{\prime}\right.$ : AACACATGCAAGTCGAACG), 356F (5'-3': ACTCCTACGGGAGGCAGCA), 515F (5'-3': GTGCCAGCMGCCGCGGTAA) and $805 \mathrm{~F}\left(5^{\prime}-3^{\prime}\right.$ : ATTAGATACCCTGGTAGTC) were used. Sequencing was performed at the DNA Sequencing Core Facility at the Beckman Institute at Caltech. The resultant sequences were edited and aligned using the ASSEMBLYLIGN ${ }^{\mathrm{TM}}$ software (IBI, Kodak Co., New Haven, CT, USA). Neighbourjoining, parsimony and maximum likelihood phylogenetic trees were constructed using the ARB freeware package (O. Strunk and W. Ludwig, Technical University of Munich; http:// www.arb-home.de/) running within the Linux environment, and the trees were compared to determine the relative robustness of the resulting phylogenetic tree topologies. The tree shown in Fig. 1 was constructed after the maximum-likelihood method using TreePuzzle within the ARB software package with 1388 positions considered (TreePuzzle is a quartet maximumlikelihood method for reconstructing tree topologies). Phylogenetic tree layout-editing was performed using TREEVIEW 1.6.6 for Windows (Page, 1996).

\section{Media and growth conditions}

Strain BoFeNl was cultivated in freshwater mineral medium prepared after Ehrenreich \& Widdel (1994). The medium was buffered at $\mathrm{pH} 6.8$ with bicarbonate. Vitamin and trace element solutions ( $1 \mathrm{~mL}$ each) and a vitamin B12 solution $(1 \mathrm{~mL})$ were added (for details and concentrations see Ehrenreich \& Widdel, 1994). This medium was used for growth with nitrate and acetate in the presence or absence of $\mathrm{Fe}(\mathrm{II})$. Bottles were closed with butyl rubber stoppers, crimped, and the headspace was flushed with $\mathrm{N}_{2} / \mathrm{CO}_{2}(\mathrm{v} / \mathrm{v}, 80 / 20)$. 


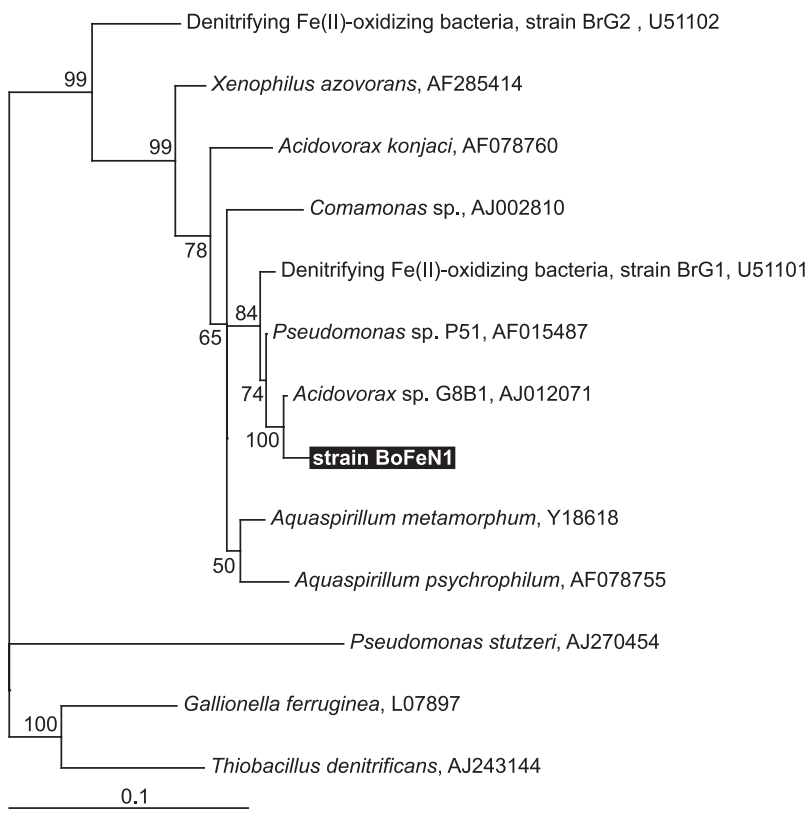

Fig. 1 16SrRNA sequence comparison of strain BoFeN1 with other strains on the basis of databank information. The tree was constructed after the maximum-likelihood method using TreePuzzle within the ARB software package with 1388 positions considered. For analyses of aligned protein sequences, 10000 puzzling steps were employed. Accession numbers are listed after the bacterium. The scale bar represents evolutionary distance as 0.1 change per nucleotide position. The numbers given are bootstrap values.

For experiments with dissolved $\mathrm{Fe}(\mathrm{II})$, the medium was transferred into an anoxic glove box, and 5-10 $\mathrm{mL}$ of an anoxic $1 \mathrm{M} \mathrm{FeCl}_{2}$ stock solution was added followed by precipitation of a whitish-grey precipitate, probably consisting of vivianite and siderite formed from phosphate and bicarbonate present in the medium. After $24 \mathrm{~h}$ the medium was filtered $(0.2 \mu \mathrm{m}$, cellulose nitrate, Millipore) leaving a clear solution with $\sim 2-6 \mathrm{~mm}$ dissolved $\mathrm{Fe}(\mathrm{II})$. In uninoculated controls, no further precipitation was observed for the duration of the incubations. This method allowed analysis of the $\mathrm{Fe}(\mathrm{III})$ precipitates formed by the $\mathrm{Fe}$ (II)-oxidizing bacteria in the absence of $\mathrm{Fe}(\mathrm{II})$ precipitates in the background. The medium $(25 \mathrm{~mL})$ was transferred into 58 - $\mathrm{mL}$ serum bottles that were closed with butyl rubber stoppers, crimped and flushed with $\mathrm{N}_{2}-\mathrm{CO}_{2}$ (v:v, 80:20). Cultures were incubated at $30^{\circ} \mathrm{C}$.

Growth of strain BoFeNl with nitrite as electron acceptor was tested with $2 \mathrm{~mm}$ acetate as electron donor and $5 \mathrm{~mm}$ $\mathrm{NO}_{2}^{-}$as electron acceptor; the turbid culture was transferred subsequently several times.

\section{Analytical methods}

For analysis of dissolved iron, $200 \mu \mathrm{L}$ culture suspension was withdrawn with a syringe and filtered over nylon $(0.22 \mu \mathrm{m})$ filter tubes (Costar, Corning, NY, USA) in an anoxic glove box. The filtrate was analysed for total dissolved Fe and for dissolved $\mathrm{Fe}$ (II) with the ferrozine assay after incubation in the presence or absence of the reducing agent hydroxylamine hydrochloride (Stookey, 1970). For analysis of total iron, $100 \mu \mathrm{L}$ suspension was added to $900 \mu \mathrm{L} 6 \mathrm{M} \mathrm{HCl}$, and incubated for $1 \mathrm{~h}$. After filtration over $0.22 \mu \mathrm{m}$ nylon filter tubes, total $\mathrm{Fe}$ and total $\mathrm{Fe}(\mathrm{II})$ were determined as above. All iron measurements with the ferrozine assay were carried out in triplicates. The standard deviation (SD) for these triplicate measurements was usually smaller than the SD calculated for different independent experiments. For analysis with ion chromatography (IC) and high-pressure liquid chromatography (HPLC), $1 \mathrm{~mL}$ samples from culture suspension were exposed to air and vortexed to rapidly oxidize remaining $\mathrm{Fe}(\mathrm{II})$ to avoid further reaction with nitrite. After complete oxidation of $\mathrm{Fe}(\mathrm{II})$, samples were filtered in nylon filter tubes $(0.5 \mathrm{~mL}$ volume, $0.22 \mu \mathrm{m}$ ) to remove all precipitates and cells. Acetate was analysed by HPLC with an Aminex HPX-87H column (Bio-Rad, Hercules, CA, USA) at $25^{\circ} \mathrm{C}$. Phosphoric acid $(30 \mathrm{~mm})$ was used as eluent in combination with a UV detector (absorbance followed at $210 \mathrm{~nm}$ wavelength). IC analysis was performed on an IonPac column (ASII, $4 \times 250 \mathrm{~mm}$, Dionex, Sunnyvale, CA, USA) at $1 \mathrm{~mL} \mathrm{~min}^{-1}$ flow rate at $35^{\circ} \mathrm{C}$ with a conductivity detector.

$\mathrm{N}_{2} \mathrm{O}$ and $\mathrm{NO}$ were quantified by gas chromatography coupled to mass spectrometry (GC-MS) directly from the culture headspace.

\section{Mineral analyses and microscopy}

\section{BET surface area}

The surface area of biogenic Fe(III) mineral precipitates was determined using the multipoint BET nitrogen adsorption technique (Micromeritics (Norcross, GA, USA) Gemini 2360 surface area analyser). After centrifugation of $300 \mathrm{~mL}$ culture and treatment of the precipitates with bleach $(\sim 5 \% \mathrm{Na}$-hypochlorite, $8 \mathrm{~h}$, room temperature) to oxidize and remove associated organic matter, the precipitates were washed with water and air dried, and the BET surface area was analysed. No change in mineral identity by this procedure was observed by X-ray diffraction.

\section{Powder X-ray diffraction}

Samples of culture suspensions were withdrawn with a syringe in an anoxic glove-box and were centrifuged to recover the precipitates. To remove remaining dissolved $\mathrm{Fe}$ (II) (to avoid oxidation and formation of nonbiogenic $\mathrm{Fe}$ (III) precipitates) the microbially produced precipitates were washed with water that had been degassed under vacuum, flushed with $\mathrm{N}_{2}$ and equilibrated under an anoxic atmosphere for several days. After spreading on a glass disk, the precipitates were dried inside the glove-box. XRD spectra were obtained on a Scintag Pad V X-ray Powder Diffractometer (Scintag Inc., Cupertino, $\mathrm{CA}$, USA) using $\mathrm{Cu}-\mathrm{K} \alpha$ radiation operating at $35 \mathrm{kV}$ and $30 \mathrm{~mA}$ with a $\theta-2 \theta$ goniometer equipped with a germanium solid-state detector. Each scan used a $0.04^{\circ}$ step size from $10^{\circ}$ to $80^{\circ}$ with 
a counting time of $2 \mathrm{~s}$ per step. Structures were identified by comparison to spectra in the PCPDFWIN program, (C) JCPDSInternational Centre for Diffraction Data, 1997 (Newton Square, PA, USA) as well as to spectra of synthetic ferrihydrite and goethite.

\section{Scanning electron microscopy (SEM)}

Per sample, a $100 \mu \mathrm{L}$ culture suspension was withdrawn with a syringe, centrifuged and washed with $300 \mu \mathrm{L}$ ultrapure anoxic water to remove medium salts. One drop of this suspension was spread on a carbon-coated copper grid (200 mesh, $3 \mathrm{~mm}$, SPI, West Chester, PA, USA) and dried under an anoxic atmosphere in the glove-box. Samples were examined by a LEO 1550VP Field Emission SEM with an Oxford INCA energy dispersive $\mathrm{X}$-ray spectroscopy unit. The system was operated at $1-15 \mathrm{kV}$ for high resolution secondary electron imaging and elemental analysis. Because of reduced beam penetration, the low voltage SEM $(<5 \mathrm{kV})$ was particularly useful in surface imaging of the uncoated fine particles.

\section{Environmental scanning electron microscopy (ESEM)}

Samples for environmental scanning electron microscopy (ESEM) were withdrawn from cultures and placed directly on an ESEM sample holder. After the precipitates/cells settled, the overlying liquid was carefully removed by wicking with a paper tissue. The residue was washed with nanopure anoxic water to remove salts present in the medium to avoid precipitation during the analysis. Samples were examined by a FEI ESEM (FEI Company, Hillsboro, OR, USA) at $20 \mathrm{kV}$ under wet mode conditions using the gaseous secondary electron (GSE) detector. The stage temperature was $4{ }^{\circ} \mathrm{C}$ with a chamber pressure of around $530 \mathrm{~Pa}$ to maintain a relative humidity of $85 \%$ at the sample. The elemental composition of the remaining mineral precipitates was determined with an EDAX detector for $60 \mathrm{~s}$ lifetime analysis.

\section{Transmission electron microscopy (TEM)}

Per sample, $5 \mathrm{~mL}$ of culture supernatants was centrifuged, fixed in $2.5-3 \%(\mathrm{v} / \mathrm{v})$ glutaraldehyde for $12 \mathrm{~h}$ at $4{ }^{\circ} \mathrm{C}$ and washed three times in water. Half of the samples were stained with $2 \%$ osmium tetroxide and $2 \%$ uranyl acetate, while the other half were left unstained. Stained and unstained specimens were dehydrated in ethanol and acetone before embedding in EPON resin. After $24 \mathrm{~h}$ at $60^{\circ} \mathrm{C}$, samples were cut on a MT-X Ultramicrotome with a $55^{\circ}$ Diatome diamond knife to $60 \mathrm{~nm}$ thickness; ultrathin sections were placed on 200 mesh copper grids. The prestained samples were subsequently poststained with $2 \%$ uranyl acetate for $3 \mathrm{~min}$ before final imaging. An Akashi EM-002B microscope operating at $100 \mathrm{kV}$ was used for microscopy and EDS. The area sampled by the Oxford spectrum analyser was approximately $8.8 \mathrm{~nm}^{2}$ at $83 \mathrm{kV}$. Acquisition rates were maintained at $10-$ $20 \%$ dead time with $60 \mathrm{~s}$ lifetime. The electron beam was defocused at the condenser lens to maintain counting rates below $1 \mathrm{kHz}$ and lifetime efficiency $>95 \%$. The EDS patterns were recorded on an INCA 3.04 Microanalysis Suite and were digitized for analysis.

\section{Confocal laser scanning microscopy}

Samples were stained with the Live-Dead dye (L-7012, Molecular Probes, Eugene, OR, USA) for imaging on an inverted Zeiss LSM 510 confocal microscope in the Biological Imaging Center at Caltech, Pasadena, CA, USA.

\section{RESULTS}

\section{Strain isolation and identification}

Strain BoFeNl was isolated from rusty-brown colonies that developed in the highest positive tubes in agar shake dilution series after $4-5$ weeks of incubation. The number of colonies corresponded to a total of $10^{5}-10^{6}$ colony-forming units per $\mathrm{ml}$ of acetate-plus-ferrous-iron-oxidizing nitrate reducers in the inoculum material. Numbers of lithotrophic, acetateindependent nitrate-reducing iron oxidizers were about two orders of magnitude lower.

16S rRNA gene sequence analysis of strain BoFeNl (Fig. 1) showed that this organism is a $\beta$-Proteobacterium, and the closest relative to this strain by $16 \mathrm{~S}$ rRNA comparison is Acidovorax sp. strain G8Bl (98.8\% identity, 1388 nucleotides considered). A nitrate-dependent $\mathrm{Fe}$ (II)-oxidizing freshwater strain (strain BrGl) also affiliated with the genus Acidovorax, but isolated from a different environment, has been described earlier (Straub et al., 2004).

\section{Oxidation of $\mathrm{Fe}(\mathrm{II})$ by strain BoFeN1}

Strain BoFeNl grew heterotrophically by oxidizing acetate with nitrate as electron acceptor. In the presence of several mM both of acetate and of dissolved Fe(II), both the acetate and the ferrous iron were oxidized and $\mathrm{Fe}(\mathrm{III})$ minerals were produced (Fig. 2A,B). No dissolved Fe(III) could be detected in the cultures. In the absence of nitrate or in uninoculated control experiments, no oxidation of $\mathrm{Fe}(\mathrm{II})$ was observed (Fig. 2A). In the presence of both $\mathrm{Fe}(\mathrm{II})$ and acetate, acetate oxidation started and a significant lag phase preceded $\mathrm{Fe}(\mathrm{II})$ oxidation (Fig. 2B). Nitrite appeared at 1.0-1.5 mu concentrations but only after $\mathrm{Fe}(\mathrm{II})$ oxidation started and not as long as only acetate was oxidized; nitrite was not formed at all in the absence of $\mathrm{Fe}(\mathrm{II})$ when strain BoFeNl oxidized acetate with nitrate as electron acceptor (data not shown). In cultures amended with dissolved $\mathrm{Fe}$ (II), acetate and nitrate, traces of $\mathrm{N}_{2} \mathrm{O}$ but no NO could be detected in the headspace. Strain BoFeNl was able to grow also with acetate as electron donor and $\mathrm{NO}_{2}^{-}$as electron acceptor (data not shown).

Strain BoFeNl needed an organic cosubstrate for fast and successive $\mathrm{Fe}(\mathrm{II})$ oxidation. At least $1 \mathrm{~mm}$ acetate was necessary to oxidize $4 \mathrm{~mm}$ dissolved $\mathrm{Fe}(\mathrm{II})$ completely to $\mathrm{Fe}$ (III) 

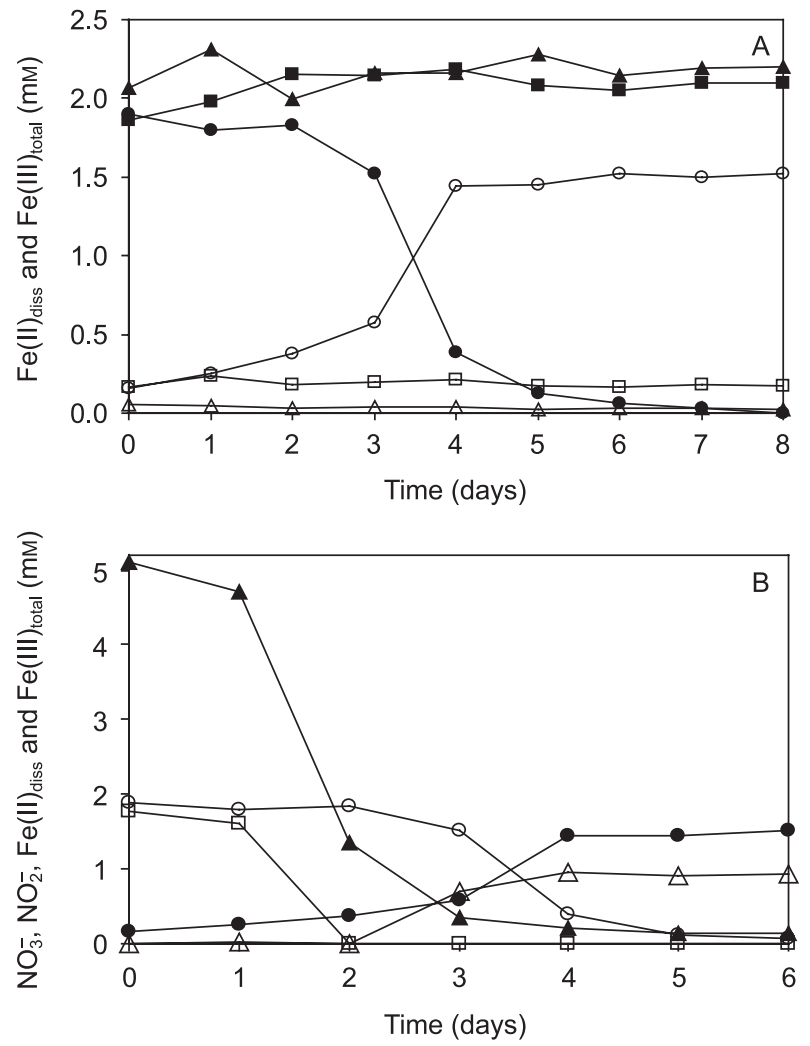

Fig. 2 Oxidation of dissolved Fe(II) by growing cultures of strain BoFeN1 (A) Representative graphs showing Fe(II) oxidation: dissolved Fe(II) (closed symbols) and $\mathrm{Fe}$ (III)total (open symbols) in the presence of Fe(II), acetate, nitrate $(\boldsymbol{O}, \bigcirc)$, in the absence of nitrate $(\square, \boldsymbol{\square})$ and in uninoculated controls $(\boldsymbol{\Delta}, \triangle)$. (B) Oxidation of acetate and dissolved $\mathrm{Fe}(\mathrm{II})$ and formation of nitrite by strain BoFeN1: acetate $(\square), \mathrm{Fe}(\mathrm{II})$ diss $(\bigcirc)$, Fe(III)total $(\bullet)$ nitrate, $\mathrm{NO}_{3}^{-}(\boldsymbol{\Delta})$, nitrite, $\mathrm{NO}_{2}^{-}(\triangle)$. All cultures were inoculated from an exponentially growing culture of strain BoFeN1 (2 mm Fe(II), $2 \mathrm{~mm}$ acetate and $5 \mathrm{~mm} \mathrm{NO}-$ ). Because of slightly different lag phases, the results from four independent experiments showing the same principle trend are not averaged. Instead, one representative data set is shown.

(Fig. 3). When we provided more acetate, the rate of $\mathrm{Fe}(\mathrm{II})$ oxidation increased slightly; omitting the acetate slowed down the oxidation rate and caused incomplete $\mathrm{Fe}$ (II) oxidation (Fig. 3). This effect was even more pronounced after a further transfer to medium containing $\mathrm{Fe}$ (II) but no acetate. After a second transfer, only negligible $\mathrm{Fe}(\mathrm{II})$ oxidation was observed at all.

\section{Cell encrustation and cell viability}

Confocal laser microscope images showed that bacteria grown with $4 \mathrm{~mm}$ dissolved $\mathrm{Fe}$ (II) plus 1 or $2 \mathrm{~mm}$ acetate have a thick crust of minerals around their cell membranes (Fig. 4). In 4 to 6-day-old cultures growing in the presence of $\mathrm{Fe}(\mathrm{II})$, a significant percentage of the cells were stained as 'dead cells' by the dead-live stain (Fig. 4). In contrast, 6-day-old cultures that were growing with acetate plus nitrate (in the absence of $\mathrm{Fe}(\mathrm{II})$ ) showed almost $100 \%$ living cells (data not shown).

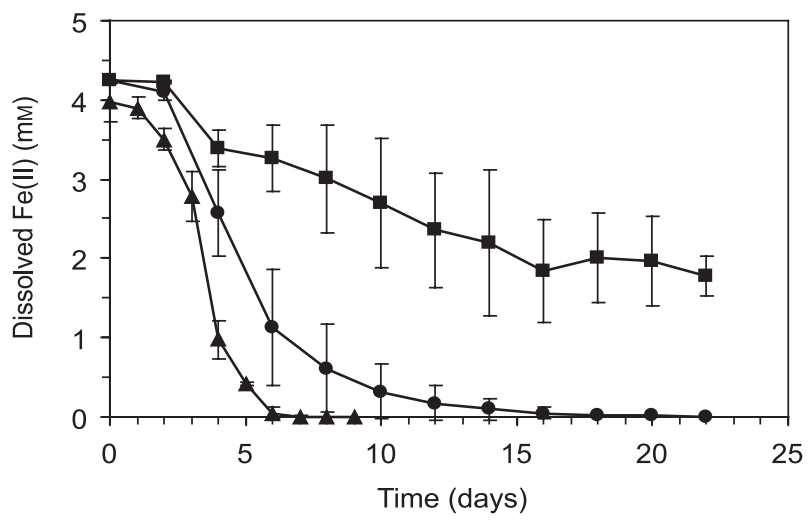

Fig. 3 Dependence of Fe(II) oxidation by strain BoFeN1 on acetate: oxidation of dissolved $\mathrm{Fe}(\mathrm{II})$ in the presence of $5 \mathrm{mM} \mathrm{NO}_{3}^{-}$and either $2 \mathrm{mM}(\boldsymbol{\Delta}), 1 \mathrm{~mm}$ acetate $(\mathbf{)})$ or in the absence of acetate $(\boldsymbol{\square})$. The cultures were inoculated from an exponentially growing BoFeN1 culture (4 mm dissolved Fe(II), 2 m $\mathrm{m}$ acetate and $5 \mathrm{~mm} \mathrm{NO} \mathrm{NO}_{3}^{-}$). The graphs shown each represent the mean of two independent cultures $( \pm \mathrm{SD})$.
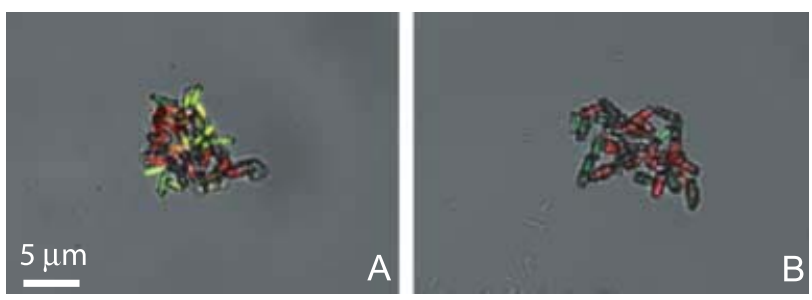

Fig. 4 Confocal microscopy pictures of 4-day-old dead-live stained cells of strain BoFeN1 (green = alive; red = dead) grown with dissolved $\mathrm{Fe}(\mathrm{II})(4 \mathrm{~mm})$, nitrate ( $5 \mathrm{~mm}$ ) and (A) $2 \mathrm{~mm}$ acetate and (B) $1 \mathrm{~mm}$ acetate showing the viability of BoFeN1 cells and different levels of cell-mineral encrustation.

Environmental scanning electron micrographs and light microscopic observations indicated that shortly after inoculation of $\mathrm{Fe}(\mathrm{II}) /$ acetate/nitrate-containing medium (before $\mathrm{Fe}(\mathrm{II})$ oxidation started) many free-floating, non-encrusted cells were present (data not shown). Mineral crusts around the cells were formed as soon as Fe(II) oxidation started (Fig. 5A), and cells were completely encrusted after all $\mathrm{Fe}(\mathrm{II})$ present in the cultures was oxidized (Fig. 5B,C).

\section{Fe(III) mineral formation and biomineralization}

After examining the influence of acetate on iron(II) oxidation, we were interested in determining the effect of the presence of pre-existing $\mathrm{Fe}(\mathrm{III})$ minerals on the mineralogy of nascent crystals. This was carried out by following the mineralogy of $\mathrm{Fe}$ (III) minerals precipitated by subcultures incubated with acetate/nitrate plus $\mathrm{Fe}(\mathrm{II})$ and inoculated either from an acetate/nitrate or from an acetate/nitrate plus $\mathrm{Fe}$ (II) starter culture. X-ray diffraction analysis of the precipitates showed the presence of the crystalline $\mathrm{Fe}(\mathrm{III})$ mineral goethite in cultures inoculated from Fe-/acetate-grown cultures. The broad background peaks present in this spectrum suggest 

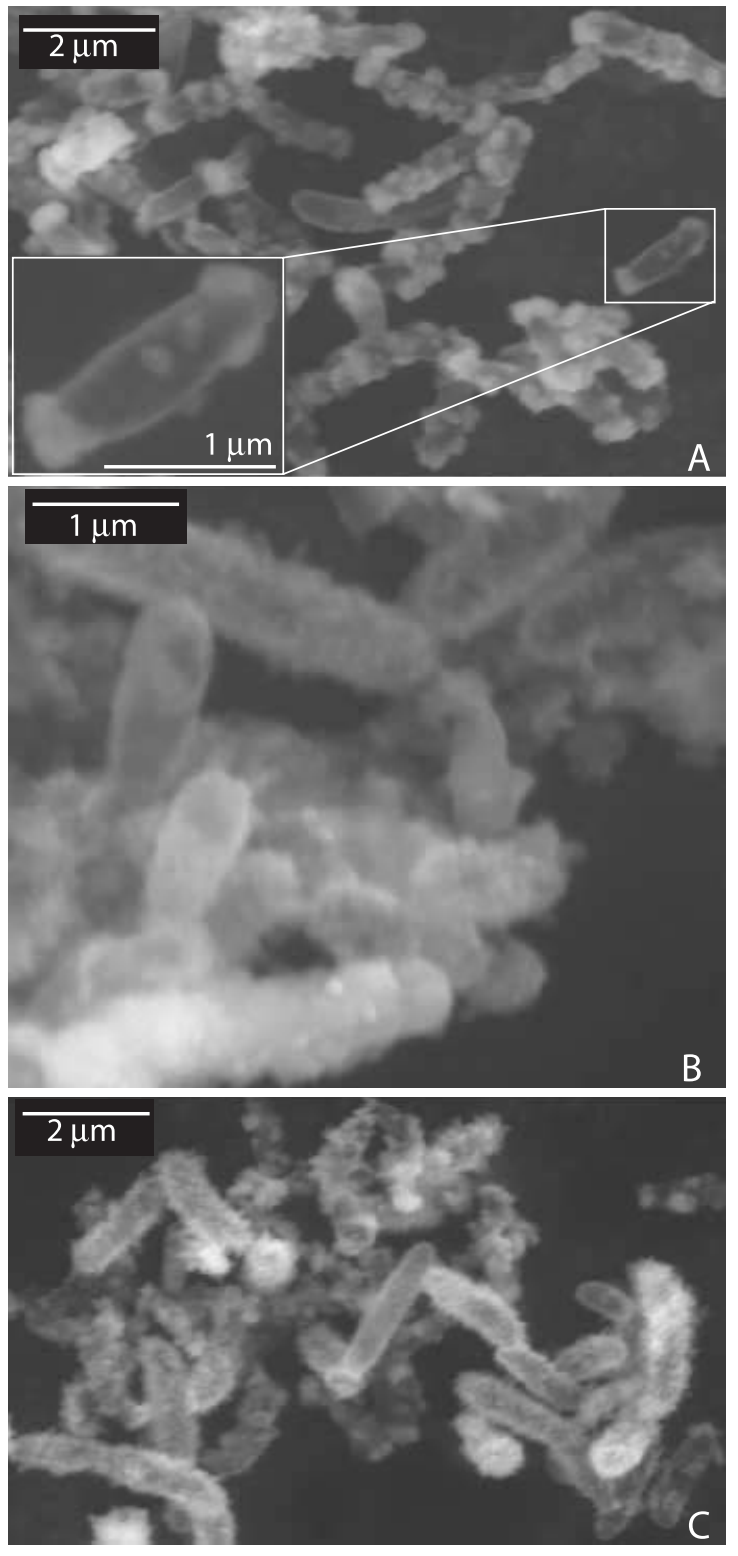

Fig. 5 Environmental scanning electron microscope photographs of cells of strain BoFeN1 grown with dissolved Fe(II) $(4 \mathrm{~mm})$, nitrate $(5 \mathrm{~mm})$ plus acetate $(2 \mathrm{~mm})$ and inoculated from a culture grown on the same substrates before. Samples were taken after 3.5 days (A), after 11 days (B), and after 30 days (C). The inset $(A)$ shows a close-up of a cell with almost no mineral precipitates on the cell surface facilitating the comparison to the encrusted cells in Figs 5B,C.

that probably also poorly crystalline iron mineral phases are present. In contrast, inoculation with cells grown with acetate in the absence of $\mathrm{Fe}(\mathrm{II})$ led only to poorly crystalline ferric iron (hydr)oxides (Fig. 6). Within 65 days, we did not observe further transformation of the minerals to other Fe(III) minerals or a further increase in crystallinity. Energy-dispersive $\mathrm{X}$-ray spectroscopy (coupled to scanning electron microscopy) of Fe minerals present in cultures inoculated with either acetate- or $\mathrm{Fe} /$ acetate-pregrown cells gave strong signals

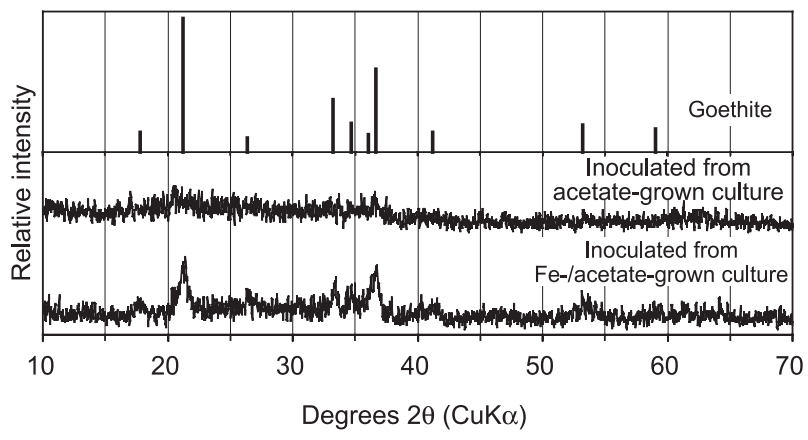

Fig. 6 X-ray diffractograms of precipitates collected from BoFeN1 cultures oxidizing dissolved Fe(II) when inoculated from a culture grown either with $\mathrm{Fe}(\mathrm{II})$, nitrate plus acetate ('Fe-/acetate-grown') or grown with nitrate plus acetate ('acetate-grown'). Reference data for goethite from the International Centre for Diffraction Data (ICDD) are included for comparison.

for iron and oxygen (data not shown). No significant signals for other elements such as phosphorus could be detected, confirming the presence of ferric iron (hydr)oxides as the main oxidation products. BET surface area analysis of poorly crystalline ferric iron (hydr)oxides obtained from a culture inoculated with an acetate-grown culture yielded a surface area of $158 \mathrm{~m}^{2} \mathrm{~g}^{-1}$.

Scanning and transmission electron micrographs of cells from cultures inoculated with cells grown either with acetate or with $\mathrm{Fe}$ /acetate confirmed that the cell encrustation and the difference in crystallinity of the $\mathrm{Fe}$ (III) mineral product depended on the history of the inoculum. When cells grown without $\mathrm{Fe}$ (II) were transferred to medium containing $\mathrm{Fe}$ (II) plus acetate, the precipitates covering the cells were small, consisting of irregularly shaped plates and needles (Fig. 7A). In contrast, when cells grown in the presence of $\mathrm{Fe}(\mathrm{II})$ were transferred to fresh medium in which they again were oxidizing $\mathrm{Fe}(\mathrm{II})$, the precipitates around the cells were larger and more crystalline as suggested already by the XRD results (Fig. 7B,C and Fig. 8).

\section{DISCUSSION}

\section{Enzymatically catalysed vs. nitrite-dependent, chemical $\mathrm{Fe}(\mathrm{II})$ oxidation}

In cultures of the nitrate-reducing bacterial strain BoFeNl amended with acetate plus nitrate, we observed oxidation of acetate with concomitant consumption of nitrate; nitrite was never observed in such cultures. However, if cultures were amended with $\mathrm{Fe}$ (II) in addition to acetate and nitrate, we observed not only oxidation of both $\mathrm{Fe}$ (II) and acetate but also concomitant accumulation of up to $1.5 \mathrm{~mm}$ nitrite. Because $\mathrm{Fe}(\mathrm{II})$ can be oxidized also chemically by nitrite (Moraghan \& Buresh, 1977), one of the initial questions was whether the observed $\mathrm{Fe}(\mathrm{II})$ oxidation was catalysed enzymatically or whether $\mathrm{Fe}$ (II) was oxidized chemically by nitrite produced during acetate oxidation. Because nitrite was 


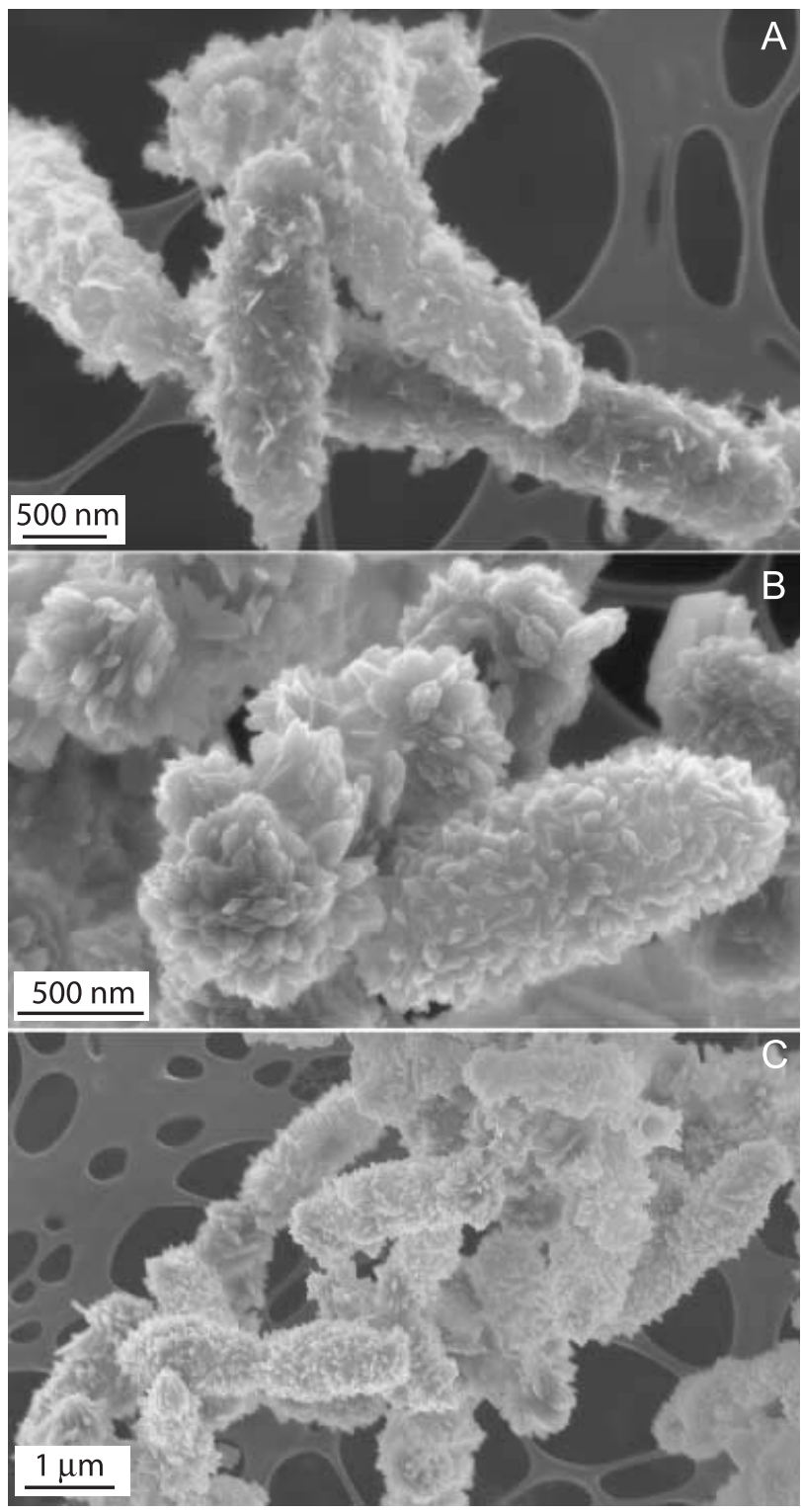

Fig. 7 Scanning electron micrographs of Fe(III)-precipitates produced by strain BoFeN1 when inoculated from a culture $(A)$ grown with acetate $(2 \mathrm{mM})$ plus nitrate $(5 \mathrm{~mm})$ and $(B-C)$ grown with acetate $(2 \mathrm{~mm})$ plus nitrate $(5 \mathrm{~mm})$ plus dissolved Fe(II) (4 mM).

never formed in the absence of $\mathrm{Fe}(\mathrm{II})$, this suggests that nitrite formation is a consequence of, but not the reason for, $\mathrm{Fe}(\mathrm{II})$ oxidation. The observed formation of nitrite during nitratedependent $\mathrm{Fe}$ (II) oxidation but not during nitrate-dependent acetate oxidation might be a consequence of the entry of electrons from the redox couples ' $\mathrm{Fe}(\mathrm{OH})_{3}, \mathrm{Fe}^{2+}$ and $\mathrm{CO}_{2} /$ acetate at different standard redox potentials $(\sim 0 \mathrm{mV}$ vs. $-290 \mathrm{mV}$; Thauer et al., 1977; Thamdrup, 2000). Entry of electrons at different redox potential levels could change the relative rates of the enzymatically catalysed reductions of the different nitrogen species, leading to the accumulation of intermediates such as the nitrite.
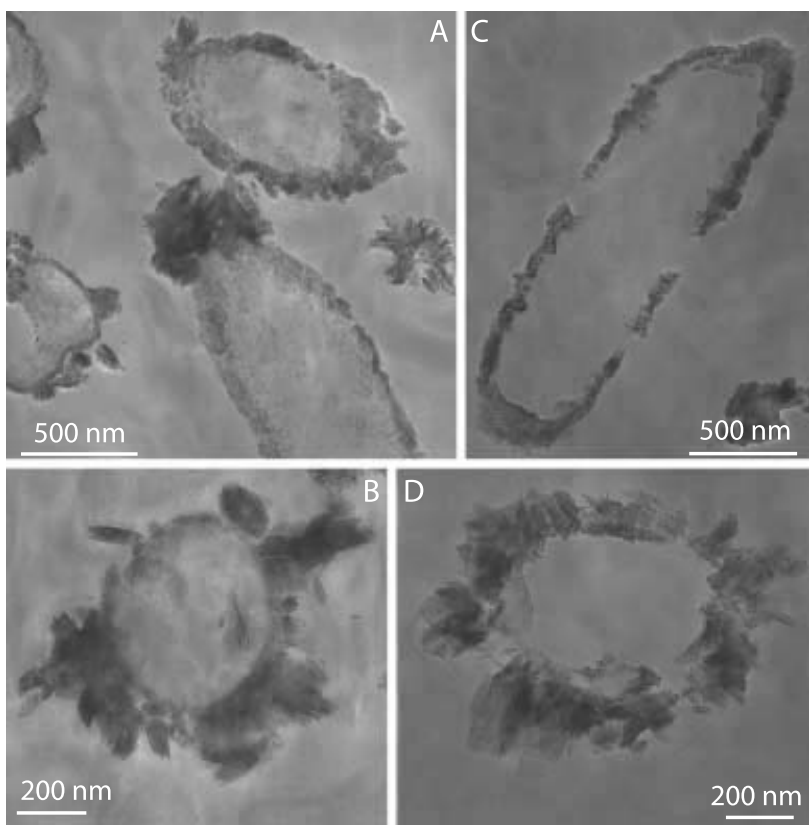

Fig. 8 Transmission electron micrographs of stained $(A, B)$ and nonstained $(C, D)$ thin sections of cells of strain BoFeN1 grown with dissolved Fe(II) (4 mM), nitrate $(5 \mathrm{~mm})$ and acetate $(2 \mathrm{~mm})$, and inoculated with a culture pregrown on the same substrates. Samples were collected after complete oxidation of Fe(II).

Comparing the rates of $\mathrm{Fe}(\mathrm{II})$ oxidation observed in BoFeNl cultures with rates of chemical $\mathrm{Fe}(\mathrm{II})$ oxidation with nitrite also supports our view that $\mathrm{Fe}(\mathrm{II})$ is oxidized in an enzymatic reaction: in sterile water amended with $0.5 \mathrm{~mm}$ nitrite and $15 \mathrm{~mm} \mathrm{Fe}(\mathrm{II})$ at $\mathrm{pH} 6.0$, about $\sim 0.07 \mathrm{~mm}$ nitrite and at pH 8 all nitrite disappeared within 24 h (Moraghan \& Buresh, 1977). The growth medium we used for cultivation of nitrate-dependent $\mathrm{Fe}(\mathrm{II})$-oxidizing bacteria contains several $\mathrm{mm}$ concentrations of different mineral salts such as sodium bicarbonate and calcium chloride as well as low concentrations of vitamins and trace elements that probably influence the oxidation extent and the oxidation rates. Such growth medium showed no significant $\mathrm{Fe}(\mathrm{II})$ oxidation with nitrite concentrations of $\sim 1 \mathrm{~mm}$; only with nitrite concentrations of $5 \mathrm{~mm}$, $\mathrm{Fe}(\mathrm{II})$ is oxidized chemically at a rate of $\sim 8 \mu \mathrm{M} \mathrm{h}^{-1}$ (Benz et al., 1998), and with $2 \mathrm{~mm}$ nitrite at $\sim 7 \mu \mathrm{M} \mathrm{h}{ }^{-1}$, including a fast initial oxidation of $\sim 40 \mu \mathrm{M} \mathrm{h} \mathrm{h}^{-1}$ during the first $24 \mathrm{~h}$ (Straub et al., 1996), which still cannot explain the Fe(II) oxidation rates we observed in our experiments $\left(50-75 \mu \mathrm{M} \mathrm{h} \mathrm{h}^{-1}\right)$. We therefore conclude that the oxidation of $\mathrm{Fe}$ (II) in our experiments is catalysed enzymatically, and is not due to an abiotic reaction of nitrite with $\mathrm{Fe}(\mathrm{II})$.

\section{Beneficial and harmful effects of Fe(III) mineral precipitation}

Strain BoFeNl oxidizes Fe(II) mixotrophically in the presence of acetate and nitrate, forming crusts of $\mathrm{Fe}(\mathrm{III})$ minerals around the cells. This is different from the nitrate-dependent 
Fe(II)-oxidizing cells described by Benz et al. (1998) who saw cells associated with the $\mathrm{Fe}$ (III) particles but not encrusted with minerals. However, these authors did not provide electron micrographs, and light microscopy could be misleading because cells that were totally encrusted and thus hidden in the minerals could have been overlooked. Moreover, these experiments were performed with brackish water medium with about $1 \%$ salt content, and the higher concentration of counter ions might have influenced the ferric oxide precipitation. Neutrophilic chemolithoautotrophic $\mathrm{Fe}(\mathrm{II})$-oxidizers that use molecular oxygen instead of nitrate as electron acceptor were isolated from the deep sea and from a $\mathrm{pH}$-neutral groundwater and were also shown to be associated but not encrusted with Fe minerals after $\mathrm{Fe}(\mathrm{II})$ oxidation (Emerson \& Moyer, 1997; Edwards et al., 2003).

It is unclear whether precipitation of $\mathrm{Fe}$ (III) minerals in close vicinity to the cells, or even at the cell surface, is harmful to the cells by virtue of limiting substrate diffusion and uptake as is commonly assumed (Hanert, 1981; Hallberg \& Ferris, 2004). At first glance, it would appear to make sense for the cell to avoid cell encrustation by locating the Fe(III) mineral precipitates distant to its surface because encrustation might limit substrate uptake. Evidence in support of this comes from a study with Acinetobacter spp., where a reduced aerobic respiration rate was observed for the cells when they were encrusted with iron (MacRae \& Celo, 1975). Production of extracellular organic material that functions to adsorb Fe(III) and nucleate precipitation (as is known for the aerobic Fe(II) oxidizers Gallionella ferruginea or Leptothrix ochracea, Hanert, 1981; Hallberg \& Ferris, 2004) could be one strategy to avoid cell encrustation. An alternative strategy could be the release of dissolved Fe(III), either complexed by organic ligands or in a colloidal state, that diffuses away and precipitates at a distance to the cell. This was suggested for microaerobic $\mathrm{Fe}(\mathrm{II})$ oxidizers that produced several $\mathrm{mm}$ dissolved or colloidal Fe(III) (Sobolev \& Roden, 2001 and 2002). A low-pH microenvironment as observed for phototrophic and microaerophilic Fe(II) oxidizers (Kappler \& Newman, 2004; Roden et al., 2004; D. Emerson, personal communication) could facilitate the release of such dissolved iron species.

Neither electron nor light microscopy of cultures of strain BoFeNl gave any indication for the involvement of extracellular organic material. We were also never able to detect dissolved $\mathrm{Fe}(\mathrm{III})$ in $\mathrm{Fe}(\mathrm{II})$-oxidizing cultures of strain BoFeNl. That strain BoFeNl obviously can overcome encrustation, and grow when fresh medium with nitrate, acetate and Fe(II) is provided compels us to reconsider whether encrustation is as harmful as generally assumed. From a thermodynamic perspective, the formation of $\mathrm{Fe}(\mathrm{OH})_{3}$ in close proximity to the cells, compared to the release and loss of $\mathrm{Fe}(\mathrm{III})$ as dissolved species, e.g. $\mathrm{Fe}^{3+}$, may even be favourable. Calculating the Gibbs free energy for nitrate-dependent $\mathrm{Fe}$ (II) oxidation with either $\mathrm{Fe}^{3+}$ or $\mathrm{Fe}(\mathrm{OH})_{3}$ as the product $\left(\mathrm{pH} 7,4 \mathrm{mM} \mathrm{Fe}^{2+}\right.$, $10 \mathrm{mM} \mathrm{NO}_{3}^{-}$and $10 \mu \mathrm{M} \mathrm{Fe}^{3+}$ in the case of $\mathrm{Fe}^{3+}$ as the product) yields a significantly lower value when $\mathrm{Fe}$ (III) is released as $\mathrm{Fe}^{3+}\left(-54.6 \mathrm{~kJ} \mathrm{~mol}^{-1} \mathrm{NO}_{3}^{-}\right)$compared to nitrate-dependent $\mathrm{Fe}(\mathrm{II})$ oxidation with precipitation of $\mathrm{Fe}(\mathrm{OH})_{3}\left(-381.3 \mathrm{~kJ} \mathrm{~mol}^{-1}\right.$ $\mathrm{NO}_{3}^{-}$). Future experiments determining growth yield and the encrustation of cells grown in chemostat experiments at limiting supply of Fe(II) and acetate could help answer the question whether $\mathrm{Fe}(\mathrm{II})$ oxidation in general and encrustation in particular are harmful or beneficial for the cells.

Our results suggest that acetate is oxidized (at least partially) before $\mathrm{Fe}(\mathrm{II})$ oxidation starts. This could help the cells to overcome cell encrustation and could lead initially to nonencrusted cells in the cultures that get encrusted concomitant with the start of $\mathrm{Fe}(\mathrm{II})$ oxidation. A preference for acetate over $\mathrm{Fe}(\mathrm{II})$ was observed also (i) with other nitrate-dependent $\mathrm{Fe}$ (II) oxidizers by Benz et al. (1998) who saw fast depletion of acetate in the beginning (and significant increase of protein content) followed by slow $\mathrm{Fe}$ (II) oxidation (and slow increase in protein content) and (ii) for Azospira oryzae (formerly known as Dechlorosoma suillum), which can oxidize $\mathrm{Fe}$ (II) mixotrophically with nitrate as electron acceptor (Chaudhuri et al., 2001; Tan \& Reinhold-Hurek, 2003). The cessation of $\mathrm{Fe}$ (II) oxidation in the absence of acetate, the ability to overcome cell encrustation in the presence of acetate and the decreasing cell viability during mineral crust formation (observed by confocal laser microscopy of dead-live stained cells) show that continuous and extensive $\mathrm{Fe}(\mathrm{II})$ oxidation by mixotrophic $\mathrm{Fe}(\mathrm{II})$ oxidizers such as strain BoFeNl depends on an organic cosubstrate.

\section{Mechanism of $\mathrm{Fe}(\mathrm{III})$ mineral formation}

Looking at chemical $\mathrm{Fe}(\mathrm{II})$ oxidation experiments (e.g. Cornell et al., 1989) might help to better understand the mechanism of $\mathrm{Fe}$ (III) mineral precipitation following microbially catalysed $\mathrm{Fe}(\mathrm{II})$ oxidation. In abiotic $\mathrm{Fe}(\mathrm{II})$ oxidation, initially, mono- and dinuclear species $[\mathrm{FeOH}]^{2+}$ and $\left[\mathrm{Fe}_{2}(\mathrm{OH} 2)^{4+}\right]$ are formed that first transform to colloidal polymers and poorly ordered ferric hydroxides (ferrihydrite, aggregates of spherical particles of $2-5 \mathrm{~nm}$ diameter), and then either transform by internal rearrangement to haematite $\left(\mathrm{Fe}_{2} \mathrm{O}_{3}\right)$ (solid-state conversion) or by decomposition of the polymers into low molecular species that transform further to crystalline forms such as goethite ('dissolution-reprecipitation mechanism'). A low-pH microenvironment as observed for phototrophic and microaerophilic Fe(II) oxidizers (Kappler \& Newman, 2004; Roden et al., 2004) could not only facilitate the release of dissolved iron species but also could catalyse the fast transformation of ferrihydrite to goethite that is possible only via a dissolution-reprecipitation mechanism. Additionally, the fast formation of goethite concomitant with the formation of a thick crust around the cells may be controlled also by an autocatalytic process: mineral-surface- $\mathrm{OH}$ groups are electron-donor ligands that increase the electron density at the metal centre, thus stabilizing $\mathrm{Fe}(\mathrm{III})$ vs. $\mathrm{Fe}(\mathrm{II})$ and leading to 
faster oxidation of $\mathrm{Fe}(\mathrm{II})$ (Wehrli et al., 1989). This effect is much stronger with goethite than with ferrihydrite (Elsner et al., 2003). Thus, the formation of goethite at the cell surface and binding of $\mathrm{Fe}(\mathrm{II})$ to the goethite surface would increase the electron density at the bound $\mathrm{Fe}(\mathrm{II})$, thus catalysing and increasing the rate of $\mathrm{Fe}$ (II) oxidation that may work via electron transfer through the mineral crust to the cell surface where the electrons could be accepted by the cell. Electron transfer from adsorbed Fe(II) to the bulk iron(III) oxide inducing growth of an $\mathrm{Fe}$ (III) layer on the oxide surface would abolish the need for the $\mathrm{Fe}$ (II)-oxidizing microbe to be in direct contact with the dissolved $\mathrm{Fe}$ (II). This idea is supported by a study that demonstrated electron transfer between $\mathrm{Fe}$ (II) adsorbed to $\mathrm{Fe}$ (III) oxides and the underlying iron(III) oxide (Williams \& Scherer, 2004).

The observed formation of goethite by strain BoFeNl differs from previous studies (Straub et al., 1996, 1998, 2004; Benz et al., 1998) in which the formation of poorly crystalline ferrihydrite by nitrate-dependent $\mathrm{Fe}$ (II) oxidizers that were transferred continuously on medium containing $\mathrm{Fe}(\mathrm{II})$ was described. While it is possible that those strains used different mechanisms for $\mathrm{Fe}(\mathrm{II})$ oxidation and $\mathrm{Fe}(\mathrm{III})$ release, the slightly different medium composition and different concentration ratios of acetate: $\mathrm{Fe}(\mathrm{II})$ :nitrate may also have influenced the mineral formation. The fact that goethite formed in our experiments only in cultures inoculated with Fe-grown cultures suggests that not only a potential low-pH microenvironment but also the presence of minerals in the inoculum that might act as nucleation sites is involved in the formation of the more crystalline $\mathrm{Fe}(\mathrm{III})$ mineral goethite. A recent study on the effect of oxidation rate on microbial nitrate-dependent $\mathrm{Fe}$ (III) mineral formation by Senko et al. (2005) showed that low initial $\mathrm{Fe}$ (II) oxidation rates can also lead to the formation of more crystalline $\mathrm{Fe}(\mathrm{III})$ minerals.

Chemical oxidation of $\mathrm{Fe}(\mathrm{II})$ by molecular oxygen $\left(\mathrm{O}_{2}\right)$ showed that the mineralogy of the produced $\mathrm{Fe}$ (III) oxides is affected by the presence of dissolved compounds such as bicarbonate, phosphate and silica (Cornell \& Schwertmann, 2003), whereas the presence of nonmetabolizing cells had no effect on the mineralogy but influenced the size, the spatial organization and the morphology of the particles (Chatellier et al., $2001,2004)$. Other authors found that in the presence of bacterial cells (Bacillus subtilis, Bacillus licheniformis), the formation of crystalline $\mathrm{Fe}$ (III) minerals was hindered and ferrihydrite formed instead (Mavrocordatos \& Fortin, 2002). These chemical oxidation experiments in the presence of nonmetabolizing cells as well as experiments of fast chemical $\mathrm{Fe}$ (II) oxidation (Cornell \& Schwertmann, 2003) favour the production of poorly crystalline $\mathrm{Fe}$ (III) oxides. The formation of goethite by strain BoFeNl and the observed variations in mineral formation observed for different nitrate-dependent $\mathrm{Fe}(\mathrm{II})$ oxidizers show that not only medium composition, concentrations of cosubstrates and incubation conditions but also $\mathrm{Fe}(\mathrm{II})$ oxidation rates and presence of nucleation sites influence and may even control the mineralogy of the $\mathrm{Fe}(\mathrm{III})$ phases produced during microbially catalysed $\mathrm{Fe}(\mathrm{II})$ oxidation.

\section{Ecological and environmental implications of $\mathrm{Fe}(\mathrm{III})$ mineral formation by nitrate-dependent Fe(II) oxidation}

The formation of poorly crystalline Fe(III) minerals such as ferrihydrite or higher crystalline $\mathrm{Fe}$ (III) minerals such as goethite by $\mathrm{Fe}(\mathrm{II})$-oxidizing bacteria has important ecological and environmental consequences. The less crystalline $\mathrm{Fe}$ (III) minerals that are produced by some nitrate-dependent $\mathrm{Fe}(\mathrm{II})$-oxidizing bacteria were shown to represent an excellent substrate for $\mathrm{Fe}(\mathrm{III})$-reducing bacteria (Straub et al., 1998), and Fe cycling by coupling microaerobic or nitratedependent $\mathrm{Fe}(\mathrm{II})$ oxidizers to $\mathrm{Fe}(\mathrm{III})$-reducing bacteria was demonstrated (Sobolev \& Roden, 2002; Straub et al., 2004). Because more crystalline $\mathrm{Fe}$ (III) minerals are difficult to reduce by $\mathrm{Fe}$ (III)-reducing bacteria (Lovley et al., 2004), the production of crystalline $\mathrm{Fe}(\mathrm{III})$ minerals might prevent microbial $\mathrm{Fe}$ (III) reduction and might be the reason for the presence of crystalline $\mathrm{Fe}(\mathrm{III})$ minerals in anoxic environments (Cornell \& Schwertmann, 2003).

Understanding the factors that influence or even control the iron cycle is important because redox reactions involving $\mathrm{Fe}$ play a major role for the fate of organic and inorganic pollutants in our environment. First, $\mathrm{Fe}(\mathrm{III})$-reducing microbes can couple the reduction of $\mathrm{Fe}$ (III) to the oxidation of organic pollutants such as aromatic hydrocarbons (see review by Lovley \& Anderson, 2000), and the presence of more crystalline and less reducible $\mathrm{Fe}(\mathrm{III})$ minerals may restrict or even hinder such degradation. Second, Fe(III) mineral precipitation can lead to coprecipitation of toxic metal ions, e.g. arsenic (Fuller et al., 1993). Coprecipitation and thus immobilization of arsenic with less or nonreducible Fe(III) minerals would be particularly desirable to avoid re-reduction of the $\mathrm{Fe}(\mathrm{III})$ that would be coupled to a release of the toxic metal ions. Third, the surfaces of $\mathrm{Fe}$ (III) (hydr)oxides adsorb nutrients such as phosphate and metal ions such as arsenate/ arsenite (Jenne, 1968; Hering, 1995). Ferric iron minerals of higher crystallinity have a significantly lower surface area (up to 50 -fold lower than the poorly crystalline ferrihydrite, Cornell \& Schwertmann, 2003) and thus a lower capacity of binding e.g. phosphate and arsenic. Reduction of nutrient- or metal-loaded ferrihydrite coupled to reoxidation producing goethite would consequently release a significant amount of either nutrients or toxic metal ions.

Knowing the mechanisms and controlling factors of anaerobic $\mathrm{Fe}(\mathrm{II})$ oxidation is important not only for understanding present-day biogeochemical cycling of iron. Precambrian oceans contained considerable amounts of dissolved ferrous iron, and at least in the beginning of that period almost no molecular oxygen $\left(\mathrm{O}_{2}\right)$ was present as a terminal electron acceptor for microbial $\mathrm{Fe}(\mathrm{II})$ oxidation. This raises the question 
how the $\mathrm{Fe}$ (II) was oxidized and precipitated in ancient Banded Iron Formations. Besides phototrophic Fe(II) oxidation, nitratedependent oxidation of $\mathrm{Fe}(\mathrm{II})$ so far represents the only known microbially catalysed mechanism to oxidize $\mathrm{Fe}(\mathrm{II})$ in the absence of $\mathrm{O}_{2}$. Moreover, it presents a mechanism for $\mathrm{Fe}(\mathrm{II})$ oxidation even in dark environments. Modelling studies aiming at understanding the relative contributions of diverse processes to $\mathrm{Fe}(\mathrm{II})$ oxidation in the past will benefit from including nitrate-dependent $\mathrm{Fe}(\mathrm{II})$ oxidation, in addition to anoxygenic phototrophs (Widdel et al., 1993; Kappler et al., 2005 ) and neutrophilic, $\mathrm{O}_{2}$-dependent $\mathrm{Fe}(\mathrm{II})$ oxidizers (Emerson \& Moyer, 1997; Edwards et al., 2003).

In summary, mixotrophic nitrate-dependent $\mathrm{Fe}(\mathrm{II})$ oxidizing bacteria oxidize $\mathrm{Fe}(\mathrm{II})$ with different rates and encrust themselves with different $\mathrm{Fe}$ (III) minerals, depending on the conditions and in particular depending on the presence of an organic cosubstrate. The identity of the produced $\mathrm{Fe}$ (III) minerals controls iron cycling and the fate of essential nutrients as well as the fate of harmful pollutants. Therefore, a thorough understanding of the factors controlling the mineralogy in this microbially catalysed process is the key for future studies.

\section{ACKNOWLEDGEMENTS}

We would like to thank E. Ottesen and Jared R. Leadbetter for help with the sequence analysis, T. Teal for help with the confocal laser microscope, R. E. Mielke for assistance with the transmission and environmental scanning electron microscopy, and N. Dalleska for help with the GC-MS and IC analysis. We would also like to acknowledge Kristina Straub and two anonymous reviewers for valuable comments that significantly improved the quality of the manuscript. The research was supported by a fellowship from the German Research Foundation (DFG) to AK and a grant from the Packard Foundation to DKN.

\section{REFERENCES}

Beaumont V, Robert F (1999) Nitrogen isotope ratios of kerogens in Precambrian cherts: a record of the evolution of atmosphere chemistry? Precambrian Research 96, 63-82.

Benz M, Brune A, Schink B (1998) Anaerobic and aerobic oxidation of ferrous iron at neutral $\mathrm{pH}$ by chemoheterotrophic nitrate-reducing bacteria. Archives of Microbiology 169, 159-165.

Blake IIR, Johnson DB (2000) Phylogenetic and biochemical diversity among acidophilic bacteria that respire iron phylogenetic and biochemical diversity among acidophilic bacteria that respire iron. In Environmental Microbe-Mineral Interactions (ed. Lovley DR). ASM Press, Washington DC, pp. 53-78.

Blake RC, Shute EA, Greenwood MM, Spencer GH, Ingledew WJ (1993) Enzymes of aerobic respiration on iron. FEMS Microbiology Reviews 11, 9-18.

Chatellier X, Fortin D, West MM, Leppard GG, Ferris FG (2001) Effect of the presence of bacterial surfaces during the synthesis of Fe oxides by oxidation of ferrous ions. European Journal of Mineralogy 13, 705-714.

Chatellier X, Fortin D, West MM, Rose J, Fortin D, Leppard GG, Ferris FG (2004) Characterization of iron-oxides formed by oxidation of ferrous ions in the presence of various bacterial species and inorganic ligands. Geomicrobiology Journal 21, 99-112.

Chaudhuri SK, Lack JG, Coates JD (2001) Biogenic magnetite formation through anaerobic biooxidation of Fe(II). Applied and Environmental Microbiology 67, 2844-2848.

Cornell RM, Schneider W, Giovanoli R (1989) The transformation of ferrihydrite into lepidocrocite. Clay Minerals 24, 549-553.

Cornell RM, Schwertmann U (2003) The Iron Oxides: Structure, Properties, Reactions, Occurrences and Uses. Wiley-VCH, Weinheim, Germany.

Croal LR, Johnson CM, Beard BL, Newman DK (2004) Iron isotope fractionation by anoxygenic $\mathrm{Fe}(\mathrm{II})$-oxidizing phototrophs. Geochimica et Cosmochimica Acta 68, 1227-1242.

Edwards KJ, Rogers DR, Wirsen CO, McCollom TM (2003) Isolation and characterization of novel psychrophilic, neutrophilic, Fe-oxidizing, chemolithoautotrophic alpha- and gamma-Proteobacteria from the deep sea. Applied and Environmental Microbiology 69, 2906-2913.

Ehrenreich A, Widdel F (1994) Anaerobic oxidation of ferrous iron by purple bacteria, a new type of phototrophic metabolism. Applied and Environmental Microbiology 60, 4517-4526.

Elsner M, Haderlein SB, Schwarzenbach RP (2003) Reactivity of $\mathrm{Fe}(\mathrm{II})$-bearing minerals towards reductive transformation of organic contaminants. Environmental Science and Technology 38, 799-907.

Emerson D (2000) Microbial oxidation of Fe(II) and Mn(II) at circumneutral pH. In Environmental Microbe-Metal Interactions (ed. Lovley DR), ASM Press, Washington DC, pp. 31-52.

Emerson D, Moyer C (1997) Isolation and characterization of novel iron-oxidizing bacteria that grow at circumneutral $\mathrm{pH}$. Applied and Environmental Microbiology 63, 4784-4792.

Emerson D, Revsbech NP (1994) Investigation of an iron-oxidizing microbial mat community located near Aarhus, Denmark: field studies. Applied and Environmental Microbiology 60, 40224031 .

Fuller CC, Davis JA, Waychunas GA (1993) Surface-chemistry of ferrihydrite. 2. Kinetics of arsenate adsorption and coprecipitation. Geochimica et Cosmochimica Acta 57, 2271-2282.

Gerhardt S, Brune A, Schink B (2005) Dynamics of redox changes of iron caused by light-dark variations in littoral sediment of a freshwater lake. Biogeochemistry 74, 323-339.

Hallberg R, Ferris FG (2004) Biomineralization by Gallionella. Geomicrobiology Journal 21, 325-330.

Hanert HH (1981) The genus Gallionella. In The Prokaryotes (eds Starr MP, Stolp H, Trueper HG, Balows A, Schlegel HG), Springer, Berlin, pp. 509-515.

Hartman H (1984) The evolution of photosynthesis and microbial mats: a speculation on banded iron formations. In Microbial Mats: Stromatolites (eds Cohen Y, Castenholz RW, Halvorson HO), pp. 451-453.

Hering ZG (1995) Implications of complexation, sorption and dissolution kinetics for metal transport in soils. In Metal Speciation and Contamination in Soil (eds Allen EA, Huang CP, Bailey GW, Bowers AR), Lewis Publishers, Boca Raton, FL, pp. 59-86.

Jenne EA (1968) Controls on $\mathrm{Mn}, \mathrm{Fe}, \mathrm{Co}, \mathrm{Ni}, \mathrm{Cu}$, and $\mathrm{Zn}$ concentrations in soils and water: the significant role of hydrous $\mathrm{Mn}$ and Fe oxides. Advances in Chemistry Series 73, 337-387.

Kappler A, Newman DK (2004) Formation of Fe(III)-minerals by $\mathrm{Fe}(\mathrm{II})$-oxidizing photoautotrophic bacteria. Geochimica et Cosmochimica Acta 68, 1217-1226. 
Kappler A, Pasquero C, Konhauser KO, Newman DK (2005) Deposition of Banded Iron Formations by photoautotrophic $\mathrm{Fe}(\mathrm{II})$-oxidizing bacteria. Geology 33, 865-868.

Lack JG, Chaudhuri SK, Chakraborty R, Achenbach LA, Coates JD (2002) Anaerobic biooxidation of Fe(II) by Dechlorosoma suillum. Microbial Ecology 43, 424-431.

Lovley DR (1991) Dissimilatory Fe(III) and Mn(IV) reduction. Microbiology Reviews 55, 259-287.

Lovley D, Anderson RT (2000) The influence of dissimilatory metal reduction on the fate of organic and metal contaminants in the subsurface. Journal of Hydrology 238, 77-88.

Lovley DR, Holmes DE, Nevin KP (2004) Dissimilatory Fe(III) and $\mathrm{Mu}(\mathrm{IV})$ reduction. Advances in Microbial Physiology 49, 219-286.

MacRae IC, Celo JS (1975) Influence of colloidal iron on respiration of a species of the genus Acinetobacter. Applied Microbiology 29, $837-840$.

Mavrocordatos D, Fortin D (2002) Quantitative characterization of biotic iron oxides by analytical electron microscopy. American Mineralogist 87, 940-946.

Moraghan JT, Buresh RJ (1977) Chemical reduction of nitrite and nitrous oxide by ferrous iron. Soil Science Society American Journal $41,47-50$

Roden EE, Sobolev D, Glazer B, Luther GW III (2004) Potential for microscale bacterial Fe redox cycling at the aerobic-anaerobic interface. Geomicrobiology Journal 21, 379-391.

Senko JM, Dewers TA, Krumholz LR (2005) Effect of oxidation rate and $\mathrm{Fe}(\mathrm{II})$ state on microbial nitrate-dependent $\mathrm{Fe}(\mathrm{III})$ mineral formation. Applied and Environmental Microbiology 71, $7172-7177$.

Sobolev D, Roden EE (2001) Suboxic deposition of ferric iron by bacteria in opposing gradients of $\mathrm{Fe}(\mathrm{II})$ and oxygen at circumneutral pH. Applied and Environmental Microbiology 67, $1328-1332$.

Sobolev D, Roden EE (2002) Evidence for rapid microscale bacterial redox cycling of iron in circumneutral environments. Antonie van Leeuwenhoek 81, 587-597.

Sobolev D, Roden EE (2004) Characterization of a neutrophilic, chemolithoautotrophic $\mathrm{Fe}(\mathrm{II})$-oxidizing $\gamma$-proteobacterium from freshwater wetland sediments. Geomicrobiology Journal 21, 1-10.

Stookey LL (1970) Ferrozine - a new spectrophotometric reagent for iron. Analytical Chemistry 42, 779-781.

Straub KL, Benz M, Schink B, Widdel F (1996) Anaerobic, nitrate-dependent microbial oxidation of ferrous iron. Applied and Environmental Microbiology 62, 1458-1460.

Straub KL, Buchholz-Cleven BEE (1998) Enumeration and detection of anaerobic ferrous iron-oxidizing, nitrate-reducing bacteria from diverse european sediments. Applied and Environmental Microbiology 64, 4846-4856.

Straub KL, Hanzlik M, Buchholz-Cleven BEE (1998) The use of biologically produced ferrihydrite for the isolation of novel iron-reducing bacteria. Systematic and Applied Microbiology 21, $442-449$.

Straub KL, Schoenhuber WA, Buchholz-Cleven BEE, Schink B (2004) Diversity of ferrous iron-oxidizing, nitrate-reducing bacteria and their involvement in oxygen-independent iron cycling. Geomicrobiology Journal 21, 371-378.

Stumm W, Morgan JJ (1996) Aquatic Chemistry: Chemical Equilibria and Rates in Natural Waters (eds Schnoor JL, Zehnder A), John Wiley \& Sons, New York, 3rd edn.

Tan ZY, Reinhold-Hurek B (2003) Dechlorosoma suillum Achenbach et al. 2001 is a later subjective synonym of Azospira oryzae Reinhold-Hurek and Hurek 2000. International Journal of Systematic Evolutionary Microbiology 53, 1139-1142.

Thamdrup B (2000) Bacterial manganese and iron reduction in aquatic sediments. In Advances in Microbial Ecology (ed. Schink B). Kluwer Academic/ Plenum Publishers, New York, pp. 41-84.

Thauer RK, Jungermann K, Decker K (1977) Energy conservation in chemotrophic anaerobic bacteria. Bacteriology Reviews 41, $100-180$.

Wehrli B, Sulzberger B, Stumm W (1989) Redox processes catalyzed by hydrous oxide surfaces. Chemical Geology 78, 167-179.

Widdel F, Bak F (1992) Gram-negative mesophilic sulfate-reducing bacteria. In The Prokaryotes (eds Balows A, Trüper HG, Dworkin M, Harder W, Schleifer KH), Springer Verlag, Berlin, pp. 3352-3378.

Widdel F, Schnell S, Heising S, Ehrenreich A, Assmus B, Schink B (1993) Ferrous iron oxidation by anoxygenic phototrophic bacteria. Nature 362, 834-836.

Williams AGB, Scherer MM (2004) Spectroscopic evidence for $\mathrm{Fe}(\mathrm{II})-\mathrm{Fe}(\mathrm{III})$ electron transfer at the iron oxide-water interface. Environmental Science and Technology 38, 4782-4790.

Wood PM (1988) Chemolithotrophy. In Bacterial Energy Transduction (ed. Anthony C), Academic Press, London, pp. 183-230. 